\title{
EFFECT OF SUB-CHRONIC ORAL ADMINISTRATION OF HYDROMETHANOLIC STEM EXTRACT OF COSTUS AFER KER GAWL. (COSTACEAE) ON LIVER AND KIDNEY FUNCTIONS IN WISTAR RATS
}

\author{
${ }^{* 1}$ Jimoh, A. A., ${ }^{2}$ Maiha, B. B., ${ }^{1}$ Chindo, B. A. and ${ }^{2}$ Ejiofor, J. I. \\ ${ }^{1}$ Department of Pharmacology and Toxicology, Faculty of Pharmaceutical Sciences, Kaduna State University, Kaduna, \\ Nigeria. \\ ${ }^{2}$ Department of Pharmacology and Toxicology, Faculty of Pharmaceutical sciences, Ahmadu Bello University, Zaria. \\ Nigeria.
}

*Corresponding Author’s Email: abdulfataijimoh@gmail.com/abdulfatai.jimoh@kasu.edu.ng

\begin{abstract}
The liver and the kidneys are two very important organs in the body and they are responsible for the metabolism and excretion of drugs respectively amongst several other functions. Severe adverse effects on these organs can lead to organ dysfunction or failure and a consequential effect on wellbeing and can even be life-threatening. This study investigated the effects of hydromethanolic stem extract of Costus afer Ker Gawl. (Costaceae) on liver and kidney function indices and the histopathology of the organs in Wistar rats. Serum liver enzymes which include: alanine amino transferase (ALT), aspartate amino transferase (AST) and alkaline phosphatase (ALP), total protein and albumin as well as serum urea, creatinine, sodium ions, potassium ions, chloride ions, bicarbonate ions were evaluated in biochemical studies. Sections of the liver and kidneys appropriately treated were examined microscopically for pathological lesions. There were decreased serum levels of ALT and ALP, but serum levels of AST increased at 500 and $1000 \mathrm{mg} / \mathrm{kg}$ doses. Serum levels of total protein (TP) and albumin concentration as well as urea and creatinine serum levels were not significantly ( $p>0.05)$ affected. However, histological examination of the liver and kidneys revealed slight to moderate hepatic necrosis and slight tubular necrosis respectively especially at 500 and $100 \mathrm{mg} / \mathrm{kg}$ doses of the extract. The results showed that the extract may be harmful to the liver and to a lesser extent the kidneys on prolonged administration and therefore it should be used with caution in such instances.
\end{abstract}

Keywords: Costus afer, kidney function, Liver function, Wistar rats

\section{INTRODUCTION}

In sub-Saharan Africa, an estimated $60-80 \%$ of the population rely on traditional medicines and healers as the primary source of healthcare (James et al., 2018). This is mainly due to easy accessibility and affordability of consulting with traditional healers as well as the perception of traditional medicine being natural and therefore safer than conventional medicine (Amira and Okubadejo, 2007; Adeyeye et al., 2011; Nxumalo et al., 2011; Adinma et al., 2015; Ahwinahwi and Chukwudi, 2016). There has been an increased interest in the use of herbal plants in recent times in many countries of the world including Nigeria (Oreagba et al., 2011; Chintamunnee and Mahomoodally, 2012; Ekor, 2013). Medicinal plants are believed to be the most abundant, affordable, reliable and well understood form of health care especially in African countries (Abalaka et al., 2009). Numerous bioactive compounds that can ameliorate some diseases and also improve the body's resistance to cellular stress are present in herbal plants (Iwalewa et al., 2007). Some of these bioactive compounds have been used as lead compounds in the manufacture of new drugs and out of the 877 novel medicines that were developed between 1981 and $2006,6 \%$ were of natural products and $16 \%$ were synthetics (Newman et al., 2008).

Costus afer Ker Gawl., commonly known as gingerlily or bush cane belongs to the family Costaceae. It is one of the 150 species of tall, perennial, and rhizomatous herbs of the genus Costus (Edeoga and Okoli, 2000). It can attain a height of up to $4 \mathrm{~m}$. It is commonly found in moist and shady forest belt of Senegal, South Africa, Guinea, Niger, Sierra Leone,
Ghana, Cameroon and Nigeria (Burkill, 1985; Edeoga and Okoli, 2000). In Nigeria, Costus afer is known as Ireke omode in Yoruba, Kakizuwa in Hausa, Okpete or Okpoto in Igboland, Mbritem in Efik. In Ijaw it is called Ogbodou, Anglophone Cameroon calls it 'Monkey sugar cane' (Anaga et al., 2004). Costus afer Ker Gawl. (Costaceae) is commonly used as a medicinal plant throughout Africa. Some of its ethnomedicinal use include anti-diabetic, anti-inflammatory and anti-arthritic (Soladoye and Oyesika, 2008), cough, malaria, veneral diseases and skin eruptions (Okoko, 2009). Although some studies on the toxicity of the stem extract on the liver (Ukpabi, et al., 2012) and of the aqueous leaf extract of Costus afer on liver and Kidney (Ezejiofor et al.,2013) of Wistar rats have been reported in literature, there is need for more toxicity studies on this plant in view of the various uses to which it is employed in traditional medicine and due to possible variation in phytochemical constituents of various plant parts as a result of differences in geographical locations, soil type and or climatic conditions. Hence, the study investigated the effects of sub-chronic oral administration of hydromethanolic stem extract of Costus afer on liver and kidney function indices as well as on the histology of the liver and kidneys of Wistar rats.

\section{METHODS}

Preparation of the extract: Three hundred grams (300g) of the powdered stem was mercerated with $1.8 \mathrm{~L} 70 \% \mathrm{v} / \mathrm{v}$ methanol (JHD, China) for 72 hours at room temperature with occasional shaking. The mixture was filtered using muslin cloth, followed by Whatman No 1 filter paper to ensure all 
debris was filtered out. The filtrate obtained was then concentrated at $45^{\circ} \mathrm{C}$ using a Rotary Evaporator (Searchtech Instruments, England. RE 52-3), under reduced pressure. The residue was dried in an oven at $45^{\circ} \mathrm{C}$. The dried extract was weighed and the percentage yield was calculated as follows:

$\%$ Yield $=$ Weight of dried extract $(\mathrm{g}) /$ Weight of powdered plant material (g) X 100

One gramme $(1 \mathrm{~g})$ of the dried extract was weighed and dissolved in $10 \mathrm{ml}$ distilled water to get a stock solution of $100 \mathrm{mg} / \mathrm{ml}$ and other concentrations were prepared by serial dilution of the stock solution on each day of the experiment.

Sub-chronic Toxicity Studies: The study was carried out according to the OECD (1995) Guideline 407 for repeated dose 28 days oral toxicity study of chemicals in Wistar rats. Forty (40) rats of both sexes (20 males and 20 females) were weighed $(160 \mathrm{~g}-220 \mathrm{~g})$ and randomized into 4 groups of 10 rats each ( 5 males and 5 females kept in separate cages based on sex). Group I (Control) rats were administered distilled water $1 \mathrm{ml} / \mathrm{kg}$ body weight, Groups II, III and IV rats received 250,500 and $1000 \mathrm{mg} / \mathrm{kg}$ body weight (LD $50>5000 \mathrm{mg} / \mathrm{kg}$, Jimoh et al., 2019) of the hydromethanolic stem extract of Costus afer orally daily respectively, for 28 days. The rats were allowed free access to food and water during the duration of the study and they were observed daily for general symptoms of toxicity (hyperactivity, sedation and salivation) and mortality. The rats were weighed once weekly and the average change in weight calculated. The rats were starved of food (and not water) overnight on Day 28 and on the $29^{\text {th }}$ day, they were first weighed and then sacrificed under light halothane anaesthesia. Blood samples were then collected through cardiac puncture for evaluation of biochemical parameters. The livers and the kidneys were harvested, weighed and examined macroscopically and were then preserved in $10 \%$ formalin prior to histological examination.

Biochemical studies: Blood samples were collected from the sacrificed rats into plain bottles, allowed to clot and centrifuged (Biobase,China. Model C200) at 3,500 rpm for 10 minutes. The separated sera were stored at $-4^{\circ} \mathrm{c}$, and used for the evaluation of serum liver enzymes which include: alanine amino transferase (ALT), aspartate amino transferase (AST) and alkaline phosphatase (ALP), total protein and albumin. Serum urea, creatinine, sodium ions, potassium ions, chloride ions, bicarbonate ions were also estimated using reagent kits (Randox Laboratories Limited, U.K) and a Colorimeter (Mediguard, China, Model 110)

Histological studies: These studies were carried out according to the methods described by Bancroft et al. (2018) in the Histology Unit, Department of Anatomy, Ahmadu Bello University, Zaria. Nigeria. Briefly: The livers and kidneys, after harvesting from the animals, were immediately fixed in $10 \%$ formalin for 48 hours. After the fixing process was completed, the tissues were processed by passing them through ascending grades of methanol from $70 \%$ to $90 \%$ and $100 \%$ for 12 hours to properly dehydrate them. The tissues were then cleared in xylene for 2 hours and then infiltrated and embedded in liquid paraffin. The tissues were then cut using Rotary Microtome (RM 2125, Leica Microsystem, Germany) at 5 micron thickness and the sections were stained using haematoxylin and eosin staining technique. They were examined microscopically for pathological lesions. The lesions were observed for the following: infiltration of lymphocytes into portal and central veins, mucosal atrophy, presence of inflammatory cells on the wall, eosinophils, lymphocytes and plasma cells.

Photomicrographs were taken at x 250 magnification.

Ethical Approval: All experiments were carried out in accordance with the guidelines and principles of the Ahmadu Bello University Committee on Animal Use and Care (Approval Number: ABUCAUC/2018/015).

Statistical Analysis: All quantitative data were expressed as mean \pm standard error of mean and presented as Tables or Plates. Data were analysed using One Way Analysis of Variance (ANOVA) followed by Bonferroni post hoc multiple comparisons test. Significant differences between means were assessed at $95 \%$ level of significance ie p-values less than or equal to $0.05(\mathrm{p} \leq 0.05)$ were considered significant. SPSS Version 20 (2011) software package was used to carry out the statistical analysis of the data.

\section{RESULTS}

\section{Mortality and Behavioural Effects}

There were no obvious signs of toxicity in the rats in the extract treated groups, but a total of five rats died within the 28 day period of the study in both the control and extract treated groups (Week 1: 1 rat in $500 \mathrm{mg} / \mathrm{kg}$ extract group, Week 2: 2 rats in control (distilled water) group and 1 rat in $1000 \mathrm{mg} / \mathrm{kg}$ extract group, Week 3: 1 rat in $1000 \mathrm{mg} / \mathrm{kg}$ extract group)

\section{Effects on Biochemical Parameters}

The hydromethanolic stem extract of Costus afer insignificantly ( $>>0.05$ ) reduced serum levels of ALT at the tested doses of 250,500 and $1000 \mathrm{mg} / \mathrm{kg}$ but not in a dosedependent way, and produced significant $(\mathrm{p} \leq 0.05)$ and dosedependent reductions in serum levels of ALP when compared with the control (distilled water) (Table 1). The effect on AST was not in a particular manner (Table 1)

The extract at doses of 250,500 and $1000 \mathrm{mg} / \mathrm{kg}$ had no significant effect $(\mathrm{p}>0.05)$ on serum total protein (TP) and serum albumin concentration when compared with the control (Table 1) 
Table 1: Effect of 28 days repeated oral administration of the hydromethanolic stem extract of Costus afer on liver function indices in Wistar rats

\begin{tabular}{|c|c|c|c|c|c|c|}
\hline $\begin{array}{l}\text { Liver } \\
\text { Indices }\end{array}$ & $\begin{array}{l}\text { Distilled water } \\
\mathrm{ml} / \mathrm{kg}\end{array}$ & 1 & HMECA $250 \mathrm{mg} / \mathrm{kg}$ & HMECA $500 \mathrm{mg} / \mathrm{kg}$ & $\begin{array}{l}\text { HMECA } \\
\mathrm{mg} / \mathrm{kg}\end{array}$ & 1000 \\
\hline ALT (iu/L) & $19.33 \pm 1.02$ & & $17.67 \pm 0.99$ & $12.33 \pm 2.17^{* \mathrm{~b}}$ & $16.00 \pm 3.14$ & \\
\hline $\operatorname{AST}(\mathrm{iu} / \mathrm{L})$ & $36.50 \pm 1.48$ & & $30.67 \pm 3.21^{\mathrm{abc}}$ & $47.33 \pm 3.90^{\mathrm{ab}}$ & $40.17 \pm 3.65^{\mathrm{ac}}$ & \\
\hline $\operatorname{ALP}(\mathrm{iu} / \mathrm{L})$ & $34.05 \pm 8.21$ & & $12.64 \pm 1.34^{* a}$ & $9.73 \pm 0.50^{* b}$ & $9.66 \pm 0.65^{* c}$ & \\
\hline $\mathrm{TP}(\mathrm{g} / \mathrm{dL})$ & $5.85 \pm 0.12$ & & $5.96 \pm 0.44$ & $5.75 \pm 0.16$ & $6.01 \pm 0.51$ & \\
\hline $\operatorname{ALB}(\mathrm{g} / \mathrm{dL})$ & $2.80 \pm 0.08$ & & $2.67 \pm 0.08$ & $2.88 \pm 0.15$ & $2.77 \pm 0.11$ & \\
\hline
\end{tabular}

Values are means \pm S.E.M, $\mathrm{n}=10$, One Way ANOVA + Bonferroni post hoc test, ${ }^{*} \mathrm{p} \leq 0.05=$ significant difference between test groups and control and common alphabets in superscripts $=$ significant difference between treatment groups at $p \leq 0.05$

HMECA = Hydromethanolic stem extract of Costus afer

$\mathrm{ALT}=$ Alanine aminotransferase

AST $=$ Aspartate aminotransferase

ALP $=$ Alkaline phosphatase

$\mathrm{TP}=$ Total protein

$\mathrm{ALB}=$ Albumin concentration

Effect of 28 days repeated oral administration of hydromethanolic stem extract of Costus afer on kidney function indices in Wistar rats

There were no significant differences ( $\mathrm{p}>0.05)$ in all the kidney function indices between the extract treated doses of 250 , 500 and $1000 \mathrm{mg} / \mathrm{kg}$ and the control (distilled water) except for potassium ions where the dose of $500 \mathrm{mg} / \mathrm{kg}$ of the extract showed a significant decrease $(\mathrm{p} \leq 0.05)$ in serum level of potassium ions when compared with the control (Table 2).

Bonferroni post hoc test showed no consistent pattern in changes in serum potassium ions levels in the extract treated groups (Table 2).

Table 2: Effect of 28 days repeated oral administration of the hydromethanolic stem extract of Costus afer on kidney function indices in Wistar rats

\begin{tabular}{llllll}
\hline $\begin{array}{l}\text { Kidney Function } \\
\text { Indices }\end{array}$ & $\begin{array}{l}\text { Distilled water } \\
\mathrm{ml} / \mathrm{kg}\end{array}$ & $\begin{array}{l}\text { HMECA } \\
\mathrm{mg} / \mathrm{kg} / \mathrm{day}\end{array}$ & $\begin{array}{l}\text { HMECA } \\
\mathrm{mg} / \mathrm{kg} / \mathrm{day}\end{array}$ & $\begin{array}{l}\mathrm{HMECA} \\
\mathrm{mg} / \mathrm{kg} / \mathrm{day}\end{array}$ & 1000 \\
\hline Urea $(\mathrm{mg} / \mathrm{dL})$ & $72.63 \pm 20.48$ & $108.88 \pm 4.91$ & $97.05 \pm 5.98$ & $83.96 \pm 16.62$ \\
Creatinine (meq/L) & $1.42 \pm 0.30$ & $1.68 \pm 0.31$ & $1.10 \pm 0.15$ & $1.33 \pm 0.18$ \\
Sodium (mmol/L) & $129.23 \pm 4.01$ & $129.32 \pm 4.17$ & $131.32 \pm 4.84$ & $133.49 \pm 3.55$ \\
Potassium (mmol/L) & $16.19 \pm 0.47$ & $16.58 \pm 0.74^{\mathrm{ab}}$ & $13.70 \pm 0.59^{*} \mathrm{abc}$ & $17.05 \pm 1.04^{\mathrm{bc}}$ \\
Chloride $(\mathrm{mg} / \mathrm{dL})$ & $31.17 \pm 3.39$ & $29.50 \pm 0.56$ & $33.83 \pm 1.66$ & $30.50 \pm 3.76$ \\
Bicarbonate (mg/dL) & $91.17 \pm 6.04$ & $101.83 \pm 3.83$ & $98.17 \pm 6.41$ & $88.67 \pm 2.16$ \\
\hline
\end{tabular}

values are means \pm S.E.M, $n=10$, One Way ANOVA + Bonferroni post hoc test, ${ }^{*} \mathrm{p} \leq 0.05=$ significant difference between test groups and control group and common alphabets in superscripts = significant difference between treatment groups (extract doses) at $\mathrm{p} \leq 0.05$

HMECA = Hydromethanolic stem extract of Costus afer

\section{Effects on Histology of Organs}

Effect on body weights and Relative Organ Weights (R.O.W)

Although there were increases in the mean body weights of rats in all the groups, percentage increases in the extract treated groups at all the doses tested were higher $(\mathrm{p}>0.05)$ than that of the mean body weights of rats in the control (distilled) group throughout the 28-day period of the study (Table 3).

The hydromethanolic stem extract of Costus afer at the doses of 250,500 and $1000 \mathrm{mg} / \mathrm{kg}$ did not cause any significant changes $(p>0.05)$ in relative weights of the livers and kidneys in the rats when compared with control group (distilled water) (Table $4)$.

Table 3: Changes in body weights of rats after 28 days repeated oral administration of the hydromethanolic stem extract of Costus afer

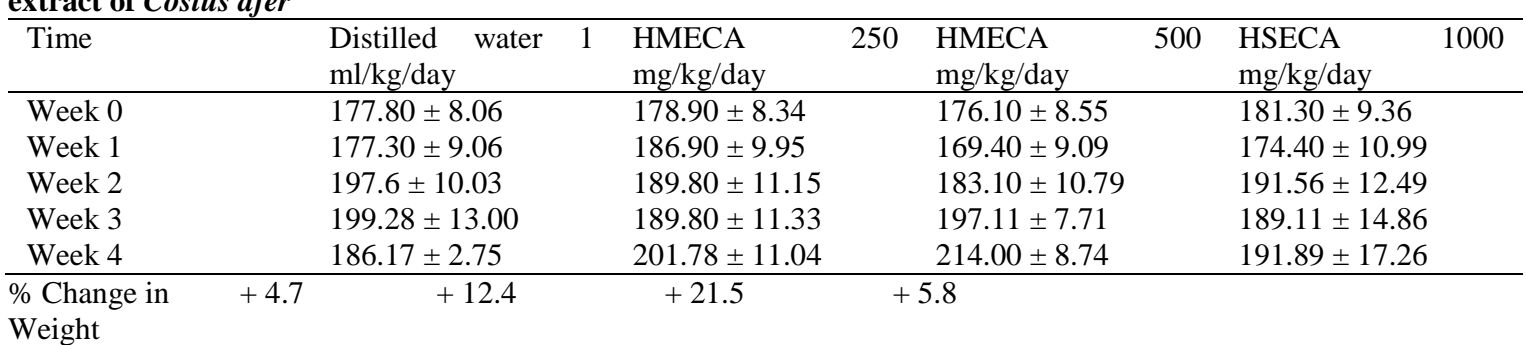


Values are means \pm S.E.M, $\mathrm{n}=10$, One Way ANOVA, $\mathrm{p}>0.05=$ No significant difference between test group and control (Distilled water).

HMECA = Hydromethanolic stem extract of Costus afer.

Table 4: Changes in relative organ weights (R.O.W) in rats after 28 days repeated oral administration of the hydromethanolic stem extract of Costus afer

\begin{tabular}{|c|c|c|c|c|c|c|c|}
\hline ORGAN & $\begin{array}{l}\text { Distilled water } \\
\mathrm{ml} / \mathrm{kg} / \text { day }\end{array}$ & $\begin{array}{l}\mathrm{HMECA} \\
\mathrm{mg} / \mathrm{kg} / \text { day }\end{array}$ & 250 & $\begin{array}{l}\mathrm{HMECA} \\
\mathrm{mg} / \mathrm{kg} / \mathrm{day}\end{array}$ & 500 & $\begin{array}{l}\mathrm{HMECA} \\
\mathrm{mg} / \mathrm{kg} / \mathrm{day}\end{array}$ & 1000 \\
\hline Liver (g) & $3.87 \pm 0.25$ & $3.81 \pm 0.09$ & & $4.08 \pm 0.27$ & & $4.02 \pm 0.33$ & \\
\hline Kidney (g) & $0.60 \pm 0.06$ & $0.64 \pm 0.03$ & & $0.68 \pm 0.06$ & & $0.71 \pm 0.08$ & \\
\hline
\end{tabular}

Values are means \pm S.E.M, $\mathrm{n}=10$, One Way ANOVA, $\mathrm{p}>0.05=$ No significant difference between test groups and control (distilled water),

HMECA = Hydromethanolic stem extract of Costus afer

\section{Effects on the liver}

The hydromethanolic stem extract of Costus afer at the doses of 250 and $500 \mathrm{mg} / \mathrm{kg}$ showed vascular congestion (VC) with lymphocyte hyperplasia (LH) and slight hepatic necrosis (HN). At the higher dose of $1000 \mathrm{mg} / \mathrm{kg}$, the liver showed moderate hepatic necrosis $(\mathrm{HN})$ as compared to rats in the control group (distilled water) which showed normal hepatocytes (Plate I).

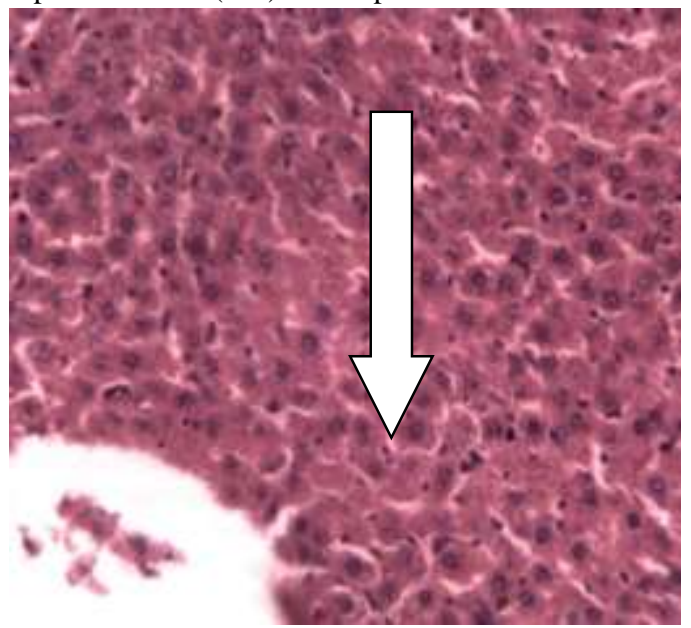

1
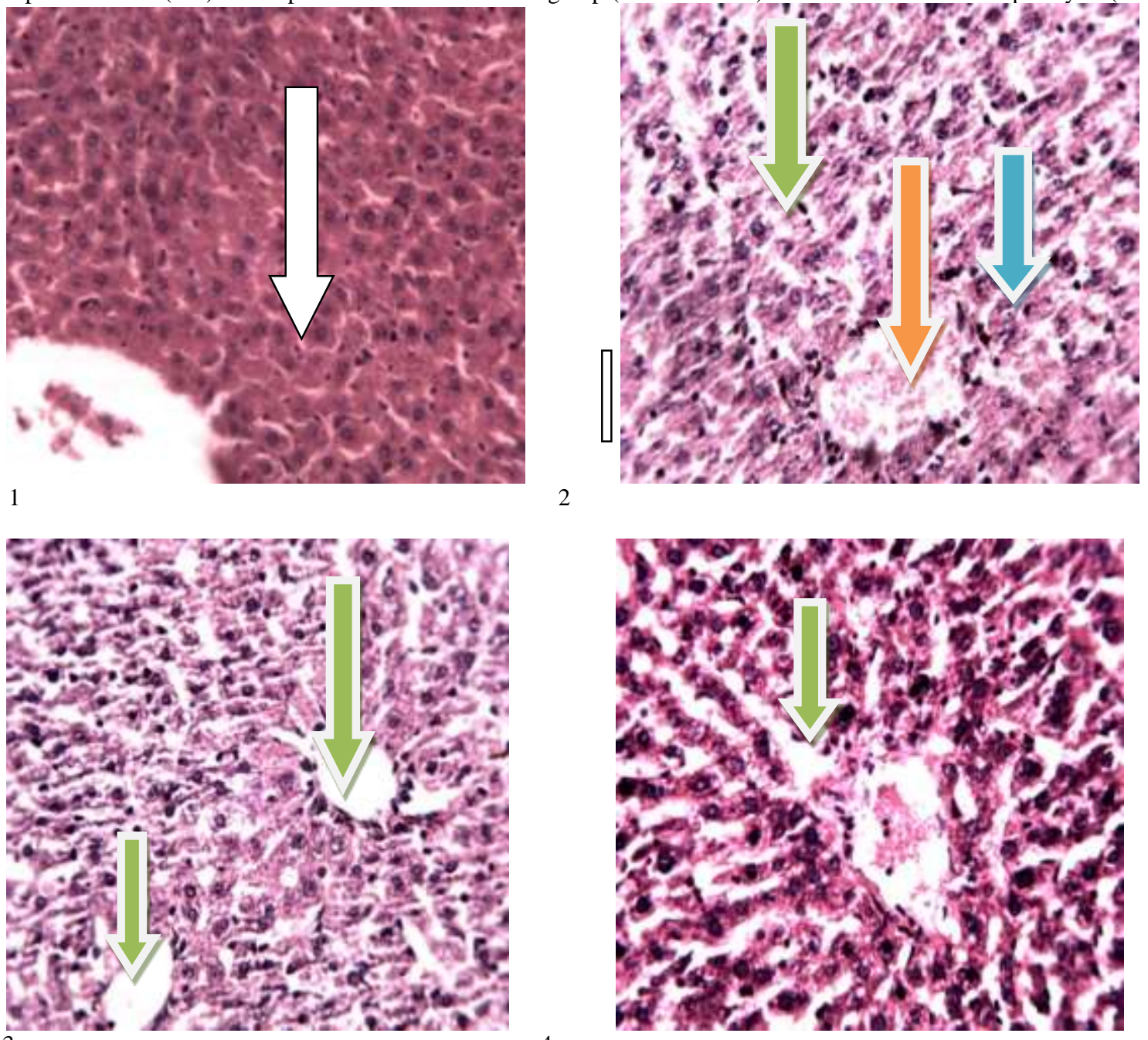
3 4

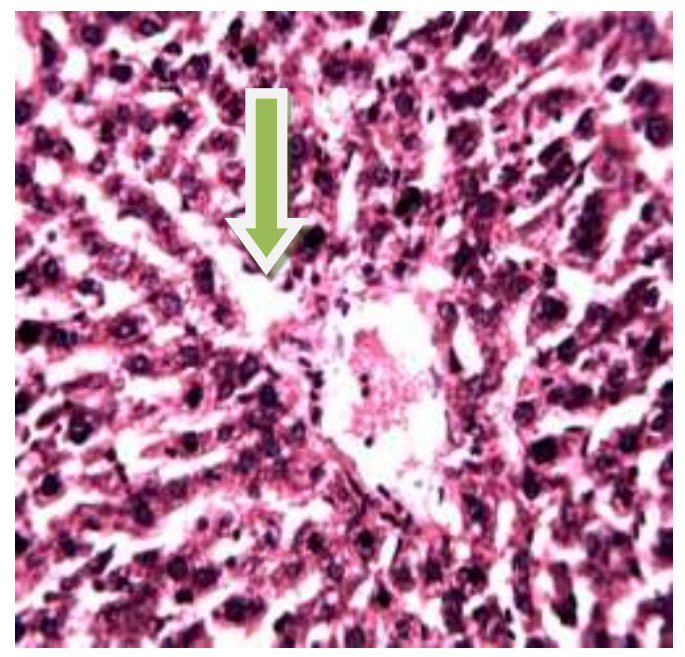

Plate I: Photomicrographs of the liver of rats administered with 250,500 and $1000 \mathrm{mg} / \mathrm{kg}$ of the hydromethanolic stem extract of Costus afer compared with control (Distilled water) $\mathrm{H}$ and $\mathrm{E}$ stain ( $\mathrm{x} 250$ magnification 
$1=$ Distilled water showing normal hepatocytes (White arrow)

$2=250 \mathrm{mg} / \mathrm{kg}$ extract showing vascular congestion (Blue arrow) with lymphocyte hyperplasia (Orange arrow) and slight hepatic necrosis (Green arrow), $3=500 \mathrm{mg} / \mathrm{kg}$ extract showing slight hepatic necrosis (Green arrow), $4=1000 \mathrm{mg} / \mathrm{kg}$ extract showing moderate hepatic necrsosis (Green arrow)

\section{Effect on the kidneys}

The hydromethanolic stem extract of Costus afer at the doses of 250, 500 and $1000 \mathrm{mg} / \mathrm{kg}$ produced slight tubular necrosis as compared to the normal glomeruli and normal tubules in the control group (Plate II).
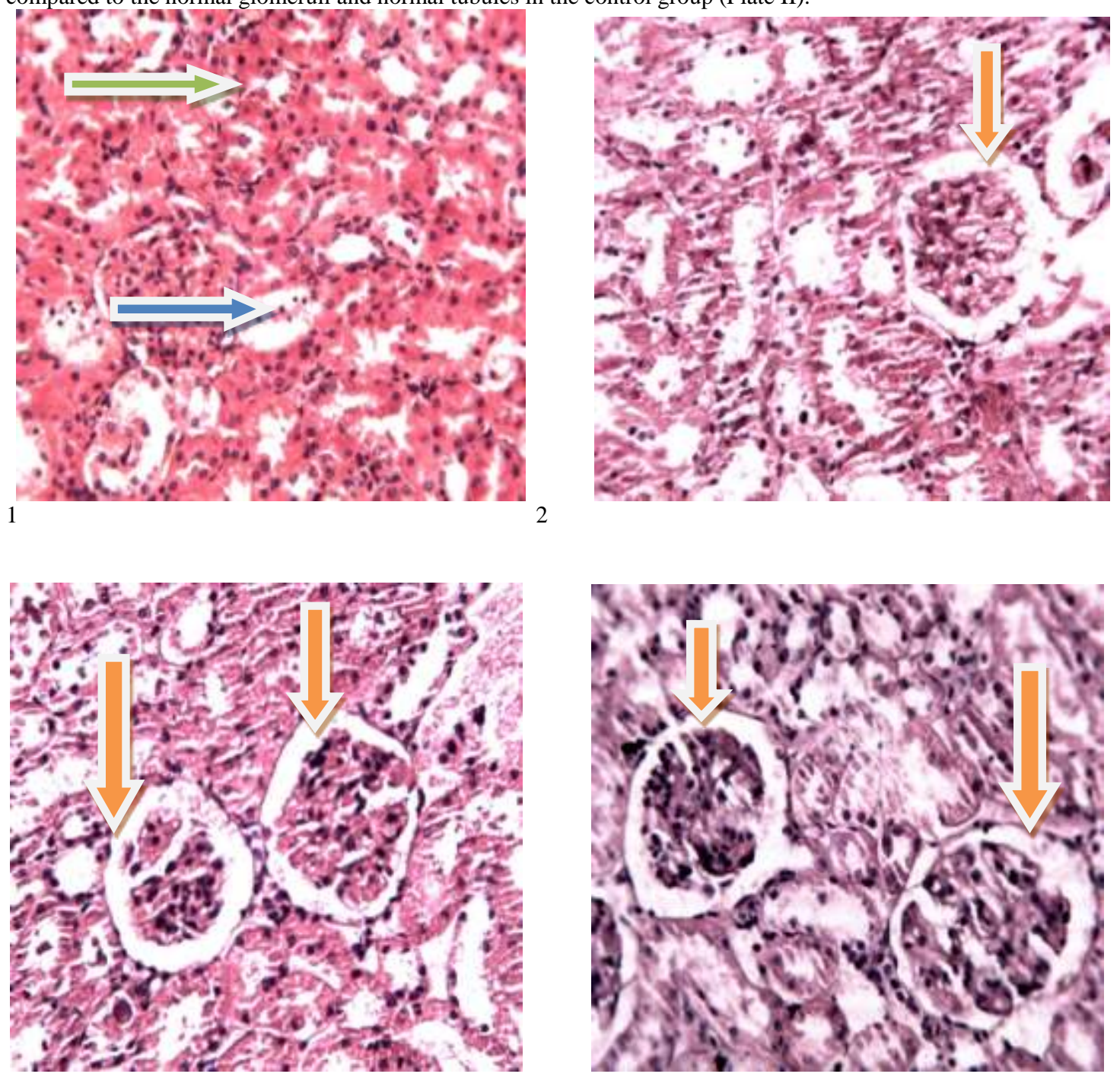

3

Plate II: Photomicrographs of the kidneys of rats administered with 250,500 and $1000 \mathrm{mg} / \mathrm{kg}$ of the hydromethanolic stem extract of Costus afer compared with control (Distilled water) $\mathrm{H}$ and $\mathrm{E}$ stain ( $\mathrm{x} 250$ magnification)

$1=$ Distilled water showing normal glomeruli (Blue arrow) and normal tubules (Green arrow)

$2=250 \mathrm{mg} / \mathrm{kg}$ extract, $3=500 \mathrm{mg} / \mathrm{kg}$ extract and $4=1000 \mathrm{mg} / \mathrm{kg}$ extract showing slight tubular necrsosis (Orange arrow)

\section{DISCUSSION}

Changes in body weights are markers of adverse effects of drugs and it is considered statistically significant if a body weight loss is more than $10 \%$ (Tepongning et al., 2018). In this study there were moderate increases in body weights of rats in all the extract treated groups but these increases were not significantly $(p>0.05)$ different from the increases in mean weights of rats in the control group. This result is important as it is an indication that feeding of the rats was not adversely affected by the administration of the extract and it can be inferred that there were no adverse effects of the extract on the body weights of rats. There were no obvious signs of behavioural toxicity in the study. However, a total of five rats died during the course of the study but this mortality involved rats in the treated groups as well as the control group and this deaths were, therefore, not likely due to the effect of the extract. The result showed that this plant is relatively nontoxic and may be safe for use in traditional medicine. Elevated serum levels of AST in the extract treated groups observed in the study as well as the vascular congestion and lymphocyte hyperplasia due to infiltration of inflammatory cells seen on 
histological examination of sections of the liver may have led to the necrosis of the hepatocytes. This result is similar to that of Ezejiofor et al. (2013) who had earlier reported likelihood of hepatotoxicity with aqueous extracts of Costus afer leaves in Wistar rats. High levels of liver enzymes could be associated with liver necrosis and other conditions that promote abnormal liver cell membrane permeability (Cameron and Greger, 1998). Cytoplasmic enzymes are only found in high concentrations in mild liver injury, while severe damage results in the release of both mitochondrial and cytoplasmic enzymes (Cameron and Greger, 1998). The liver damage in this study was mild to moderate and it was likely due to the elevated serum levels of AST. Alkaloids and especially pyrrolizide alkaloids (PAs) induce hepatocyte necrosis that may progress to liver failure (Diaz, 2015). Hydrolyzable tannins or products of their degradation such as pyrogallol are hepatoxic (Reed, 1995) and the tannins and alkaloids in the hydromethanolic extract of Costus afer may have caused the hepatic necrosis observed on histological examination of the liver of Wistar rats in this research.

Assessment of the kidney function is very important in toxicity evaluation of drugs and plant extracts as they are both necessary for the survival of the organism (Ezejiofor et al., 2013). Measurements of serum levels of urea and creatinine are usually performed to evaluate kidney function (Arsad et al., 2013). Both serum creatinine and urea levels are elevated in patients with renal malfunction, especially decreased glomerular filtration. In the early stage of kidney damage, increase in serum urea level usually precedes the increase in serum creatinine that is observed in chronic kidney damage (Craig, 2007). Serum creatinine is a significantly more reliable renal function screening test than serum urea because serum urea levels may be affected by dehydration, diet and protein metabolism, which do not affect serum creatinine levels. In this study there were increases $(p>0.05)$ in the serum levels of urea, creatinine, sodium ions, chloride ions and bicarbonate ions in all extract treated groups when compared with the control group (distilled water). The elevated serum urea levels may be an indication of early kidney damage and this is supported by the result of histological examination of the kidneys which showed slight tubular necrosis at all the extract treated doses and this will likely affect the efficient reabsorption of minerals and fluids from urine as it forms. The toxic effect on the liver and kidneys may be due to the presence of alkaloids in the extracts which can interfere with membrane permeability, membrane proteins (ion channels and receptors), enzymes and other proteins, DNA, RNA and corresponding proteins, electron chain and the cytoskeleton (Wink, 2016). The result of this study is in contrast to that of Ezejiofor et al., 2013 who reported non-toxicity of the aqueous leaf extract of Costus afer on the kidneys of male albino Wistar rats in both biochemical and histological examination of the kidneys and this may be due to differences in phytochemical constituents.

\section{CONCLUSION}

The result of this study showed that the hydromethanolic stem extract of Costus afer Ker Gawl. (Costaceae) may be toxic to the liver and kidney on prolonged administration at the doses used in this study and therefore caution should be exercised when the plant is used to treat chronic disease conditions in traditional medicine.

\section{CONFLICT OF INTEREST}

The authors declare that there are no conflicts of interest regarding the publication of this article.

\section{ACKNOWLEDGEMENTS}

The authors are grateful to Mr Bitrus Achi of the Department of Pharmacology and Toxicology, Kaduna State University, Kaduna and Mr Bamidele Adetiba of the Department of Anatomy, Ahmadu Bello University, Zaria, Nigeria for their technical assistance.

\section{REFERENCES}

Abalaka, M. E., Olonitola, O. S., Onaolapo, J. A. and Inabo, H. I. (2009). Evaluation of acute toxicity of Momordica charantia Extract using Wistar Rats to Determine Safety Levels and Usefulness of Plant in Ethnochemotherapy. Int. J. Appl. Sci., 3:1-6.

Adeyeye, O., Onadeko, B., Ogunleye, O. (2011). The use of complementary and alternative medicine by asthma patients receiving care in an urban tertiary centre in Nigeria. Int. $J$. Biol. Med. Res., 4: 1026-1030.

Adinma, E., Azuike, E., Okafor-Udoh, C. (2015). Pattern and practice of complementary and alternative medication amongst patients in a tertiary hospital in Nigeria. Eur. J. Prev. Med., 3: 44-48.

Ahwinahwi, U., Chukwudi, K. (2016). Perception and use of Complimentary and Alternative Medicine (CAM) among undergraduate students in a Nigerian University. J. Appl. Pharm., 6:096-101.

Amira, O.C., Okubadejo, N.U. (2007). Frequency of complementary and alternative medicine utilization in hypertensive patients attending an urban tertiary care centre in Nigeria. BMC Complem. Altern. Med., 7:30.

Anaga, A.O., Njoku, C.J., Ekejiuba, E.S., Esiaka, M.N., Asuzu, I.U. (2004). Investigations of the methanolic leaf extract of Costus afer Ker-Gawl for pharmacological activities in vitro and in vivo. Phytomedicine, 11 (2-3): 242248.

Arsad, S.S., Esa, N.M., Hamzah, H., Othman, F. (2013). Evaluation of acute, sub-acute and sub-chronic oral toxicity of Raphidophora decursiva (Roxb.) Schott extract in male Sprague Dawley rats. J. Med Plant Res., 7 (4): 3030-3040.

Bancroft, J.D., and Clayton, C. (2018). The Hematoxylins and Eosin. In: Survana, S.K., Layton, C., and Bancroft, J.D. (Eds): 
Bancroft's Theory and Practice of Histological Techniques. $8^{\text {th }}$ Edition, Elsevier, China. Page 126-138.

Burkill, H.M. (1985). The useful plants of West Tropical Africa. $2^{\text {nd }}$ Edition. Volume 1, Families A-D. Royal Botanical Gardens, Kew, Richmond, United Kingdom, 960pp.

Cameron, J.S. and Greger, R. (1998). Renal Function and Testing of Function. In: Davidson, A.M., Cameron, J.S., Grunfield, J.P., Kerr, D.N.S., Rits, E., Winearl, G.C. (Eds). Oxford Textbook of Clinical Nephrology, Oxford University Press, Oxford. pp36-39.

Chintamunnee, V. and Mahomoodally, M. F. (2012). "Herbal Medicine commonly used against Infectious Diseases in the Tropical island of Mauritius," J. Herb. Med., 2:113-125.

Craig, R.G. (2007). Interactions between chronic renal disease and periodontal disease. Oral Dis., 1491: 1-7.

Diaz, G.J. (2015). Toxicosis by plant alkaloids in humans and animals in Colombia. Toxins, 7(12): 5408 - 5416 doi: $10.3390 / 26690479$.

Edeoga, H.O. and Okoli, B.E. (2000). Chromosome numbers of Costus lucanusianus (Costaceae) in Nigeria. Folia Geobot., 35: 315-318.

Ekor, M. (2013). The growing use of herbal medicines: issues relating to adverse reactions and challenges in monitoring $\begin{array}{llll}\text { safety. } & \text { Front. } & \text { Pharmacol., } & \text { 4, }\end{array}$ http://doi.org/10.3389/fphar.2013.00177

Ezejiofor, A.N., Orish, C.N. and Orisakwe, O.E. (2013). Effect of aqueous leaves extract of Costus afer Ker Gawl (Zingiberaceae) on the liver and kidney of male albino Wistar rats. Anc. Sci. Life, 33 (1): 4-9. doi: 10.4103/02577941.134554. PMCID: 4140021.

Iwalewa, E. O., Lege-Oguntoye, L., Rai, P. P. and Iyaniwura, T. T. (2007). In vivo and in vitro antimalarial activity of two crude extracts of Cassia occidentalis leaf. Niger. J. Pharm,, 5: $23-28$

James, P.B., Wardle, J., Steel, A. and Adams, J. (2018). Traditional, Complementary and Alternative Medicine use in sub-Saharan Africa: A Review. BMJ Global Health, 3(5): 1-
18. BMJ Global Health 2018, 3:e000895, doi:10.1136/bmjgh2018-000895.

Jimoh, A.A., Maiha, B.B., Chindo, B.A. and Ejiofor, J.I. (2019). Antiplasmodial Activity of the Methanol Stem Extract of Costus Afer Ker Gawl. (Costaceae) in Mice. Nigerian Journal of Pharmaceutical and Biomedical Research, 4(1): 30 - 39 .

Newman, D. J. (2008). Natural products as leads to potential drugs: an old process or the new hope for drug discovery? $J$. Med. Chem., 51: 2589-2599.

Nxumalo, N., Alaba, O., Harris, B., Chersich, M., Goudge, J. (2011). Utilization of Traditional Healers in South Africa and costs to patients: Findings from a National Household Survey. J. Public Health Policy, 32 (suppl 1): 124-136.

OECD (1995). Repeated dose 28 days oral toxicity study in rodents. OECD guideline for the testing of chemicals 407: 18.

Okoko, T.C. (2009). Stem extracts from the monocot Costus afer ameliorates paracetamol induced tissue injury in rats. Int.

J. Pure Appl. Sci., 3: 21-25

Okugbo, T. and Oriakhi, K. (2015). A Comparative study of in vitro antioxidant activity and Phytochemical Constituents of Methanol Extract of Aframomum melegueta and Costus afer Leaves. Jordan J. of Biol. Sci., 8 (4) : 273-279.

Oreagba,I. A., Oshikoya, K. A. and Amachre, M. (2011). Herbal medicine use among urban residents in Lagos, Nigeria. BMC Complem. Altern. Med.,11: 117. doi: 10.1186/1472-6882-11-117

Ukpabi, C.F., Agbafor, K.N., Ndukwe, O.K., Agwu, A. and Nwachukwu, S.N. (2012). Phytochemical composition of Costus afer extract and its alleviation of carbon tetrachlorideinduced oxidative stress and toxicity. Int. J. Modern Bot., 2 (5): 120-126.

Reed, J.D. (1995). Nutritional toxicology of tannins and related polyphenols in forage legumes. J. Animal Sci., 73(5): 1516-1528. https://doi.org/10.2527/1995.7351516x 
Soladoye, M.O. and Oyesika O.O. (2008). Textbook of Medicinal Plants from Nigeria, University of Lagos Press, Nigeria. pp628

Survana, S.K., Layton, C., Bancroft, J.D. (2018). Bancroft's Theory and Practice of Histological Techniques. $8^{\text {th }}$ Edition, Elsevier, China. ISBN_9780702068645.537p

Tepongning, R.N., Mbah, J.N., Avoulou, F.L., Jerme, M.M., Ndanga, E-K, K. and Fekam, F.B. (2018). Hydroethanolic extracts of Erigeron floribundus and Azadirachta indica reduced Plasmodium berghei parasitaemia in Balb/c Mice. Evidence-based Complementary and Alternative Medicine. 2018: 5156710. doi: 10.1155/2018/5156710.
Tonkiri, A., Essien, E.B., Akaninwor, J.O. and Ogbomade, R.S. (2015). Protective effect of Costus afer on lipid profile and hepatic damage in ethanol-induced liver cirrhosis in rats. Int. J. Biochem. Res. \& Rev., 6 (2): 53-61.

Wink, M. (2016). Alkaloids: Toxicology and Health Effects. DOI: 10.1016/B978-0-12-384947-2.00020-9

Wolfe, D. (2018). Tissue processing. In: Survana, S.K., Layton, C., and Bancroft, J.D. (Eds): Bancroft's Theory and Practice of Histological Techniques. $8^{\text {th }}$ Edition, Elsevier, China. Page 73-83. 